Reprod. Nutr. Dévelop., 1980, 20 (3 B), 801-806.

\title{
Sound stimulation available to the sheep foetus
}

\author{
par Margaret A. VINCE, Sally E. ARMITAGE
}

MRC External Staff, at the ARC

Institufe of Animal Physiology,

Babraham, Cambridge, CB2 4AT, U.K.

Summary. Work on the uterine sound environment has been carried out by implanting a hydrophone on the neck of the fœetus in two pregnant ewes a few weeks before term. Stimulation with sounds of known amplitude and the use of calibrated microphones and a frequency analyser enabled us to assess (1) the amount of attenuation of sounds of different frequency when they had passed through the maternal tissues and amniotic fluid to become available to the foetus, (2) the absolute level of sound entering the amnion from within the mother and (3) the recognizability of external sound such as speech, when recorded from within the uterus. One puzzling feature of the results has been our inability to hear those sounds which are commonly believed to constitute a predominant stimulus for the fœetus : those produced by the maternal cardiovascular system.

Over the last decade there has been an upsurge of interest in the mammalian foetal sound environment. This environment is believed to consist predominantly of loud pulsations from the mother's cardiovascular system, and from the main arteries and the placenta (Murooka, 1976). We are going to suggest that this idea may be based on a misunderstanding : recordings in human subjects have been made from the cervix at, or before, term or in a goat at various stages of gestation from the outside of the uterine wall. But no-one, so far as we know, has reported recording the mammalian foetus' actual sound environment : the sounds available to it in its fluid environment within the amniotic sac.

Prenatal sound experience is believed to have a tranquillizing effect on the neonate after birth (Salk, 1960 ; Murooka, 1976). Assuming that the fœetus hears sounds, and especially repetitive sounds, from inside or outside the mother, there is reason to suggest that this experience could play some part in development. This is known to be the case in certain species of birds, in which controlled experimental work can be carried out more easily than in mammals. For example, the guillemot embryo comes to recognize its own parents'voices while still in the egg (Tschanz, 1986); similarly, laughing gull chicks which have heard the parental feeding call before hatching peck more readily for food than do chicks without this prehatching experience (Impekoven, 1971). According to Gottlieb (1971), prehatching experience of sibling calls is needed for Peking ducklings to discriminate maternal calls of their own species. 
It is obvious that the acoustic situation within an egg is different from that in the uterus ; one important problem is whether the foetus hears sounds from outside the mother. The fœtus is enclosed by the uterine and body walls as well as by membranes and fluid ; some reports indicate that external sound is greatly attenuated and, in addition, may be masked by internal noise. Grimwade, Walker and Wood (1970) have recorded from a microphone placed against the fœtal head in the lower uterine segment at term in human subjects and report low frequency sound at a level of 85-94 $\mathrm{dB} S P L$, the peaks occuring in time with the maternal pulse. They report attenuation of external sound through the body wall and uterus of $39 \mathrm{~dB}$ at $500 \mathrm{~Hz}$, rising at $5 \mathrm{kHz}$ as high as $85 \mathrm{~dB}$ SPL. Recording at the cervix in one multiparous subject of 37 weeks gestation, Bench (1968) reports internal background sounds - a rhythmic noise in time with the mothers' pulse - of $72 \mathrm{~dB}$; attenuation of outside sound varied from $19 \mathrm{~dB}$ at $200 \mathrm{~Hz}$ to $48 \mathrm{~dB}$ at 2000 and $4000 \mathrm{~Hz}$. In the goat, Bench, Anderson and Hoare (1970) have recorded from a hydrophone sutured to the external uterine wall. They note internal noise at a level of about $73 \mathrm{~dB}$ SPL. They also report that sounds of between 500 and $2000 \mathrm{~Hz}$, generated externally, had to be at a level between 89 and $98 \mathrm{~dB}$ SPL to be picked up by the internally implanted hydrophone.

Nevertheless, Grimwade, Walker and Wood (1970) and Bench and Mentz (1975) report that very loud sounds (100-120 dB SPL) directed at the fotus from outside the mother were followed by fotal heart rate changes.

A question raised by this work is whether sound conditions inside the amniotic sac are the same as those outside. Assuming that this is not necessarily the case, we have carried out experiments to test the possibility that a precocial mammalian fotus can hear external sounds at a somewhat lower level ( $90 \mathrm{~dB}$ SPL) before birth and also that this prenatal sound experience affects its postnatal behaviour. In the guinea pig (Vince 1979) pregnant animals were stimulated daily with a repetitive, mildly aversive, alien sound. Their offspring were then tested with the same sound and the neonates' response, measured as heart rate change, was compared with that of young animals which had not heard the stimulus sound before birth. This second group gave marked heart rate changes in response to the sound stimulus, while the prenatally stimulated group appeared to be already habituated to the sound and their heart rate responses were smaller. Currently a similar experiment is being carried out in the sheep in which sound attenuation through the body wall might be expected to be greater than in the guinea pig ; although this experiment is not yet complete, it is providing interesting results.

Given this amount of encouragement we have begun to look in some detail at the immediate sound environment - within the amniotic sac - of a precocial mammalian fœtus, in this case, the sheep. The problems we are concerned with are two : (i) what sounds from within the mother are likely to be available to the fœtus and at what level do they occur, and (ii) to what extent can sounds from outside the mother be picked up inside the amniotic sac and how much are they attenuated? This work has been made possible by Dr. B. A. Baldwin, of the Institute of Animal Physiology Babraham, who has successfully implanted listening devices, first inside the body wall of a ram and more recently inside the uterus (in fact inside the amniotic sac) in two pregnant ewes. In each of the last two cases the device was sutured to the fotal neck. 
Our implanted sound transducer was an LC 10 hydrophone produced by Celesco Industries Inc. This has a flat frequency response over a wide range : 0,1 to $100 \mathrm{kHz}$. For measuring the level of external sound we have used either a Sennheiser probe microphone, which also has a flat frequency response, or a Dawe sound level meter working with the «C » weighting, also relatively flat. The hydrophone and microphone amplifiers were constructed so that the two systems were of approximately equal sensitivity. Measurements of attenuation of external sounds and uterine sound level were made by means of a Bruel and Kjaer Narrow Band Spectrum Analyser Type 2031, into which hydrophone and microphone systems could be fed directly.

We made few quantitative measurements from the first two implanted animals (one ram and one ewe) but the subjective impression obtained from them was instructive. On the basis of other authors' work we expected to hear heart beats and the sound of rumination and to record a considerable attenuation of external sounds. We heard, in fact, rather little internal sound unless the animal was engaged in some specific activity, such as eating or drinking, or was excited in some way when, as in the ewe, the sound of breathing became prominent. We could detect nothing which could be interpreted as the sound of the maternal heart or cardiovascular system. External sounds were atfenuated, but were recognizable, for example, recordings from inside the body wall (in the ram) or from inside the amniotic sac (in the ewe) were found to include comprehensible passages of our own quiet conversation as we sat working by the animals.

Quantifative measures were taken in the main from our second implanted ewe. This was a Clun Forest sheep, a larger, fatter and heavier animal than the other (a Dalesbred), and with a dense $4^{\prime \prime}$ fleece, except over the abdominal area which had been shaved before the operation. Subjectively, there seemd to be more affenuation of external sound in this animal than in the Dalesbred ewe.

Attenuation was measured in two different ways. In the first we fed recordings of a patterned sound (a bleat) into a $100 \mathrm{~mm}$ loudspeaker strapped against a shaved area of the animal's skin, but separated from it by a $1^{\prime \prime}$ annulus of foam rubber. The loudspeaker output was measured on the outside of the animal by inserting the end of the probe microphone between the speaker and the skin. The outputs of the microphone and the implanted hydrophone were fed directly into the Spectrum Analyser and, as the two systems were of comparable sensivity, attenuation could be read off the records as the difference between peaks from the two transducers. Readings up to $4 \mathrm{kHz}$ were made. Between 2 and $4 \mathrm{kHz}$ attenuation of 15 to $20 \mathrm{~dB}$ occurred. Below $2 \mathrm{kHz}$ attenuation increased, including differences up to $35 \mathrm{~dB}$, but below $600 \mathrm{~Hz}$ the difference between peaks lessened again.

These findings were then checked using a different method. Pure tones from a function generator were fed to an amplifier and to a large loudspeaker facing the sheep. A sound level meter ( $C$ C » scale) was used to assess the amplitude of the external tone against the sheep's flank. For each tone this external sound level was compared with the output from the implanted hydrophone system connected directly with the Spectrum Analyser: the internal sound level was subtracted from the reading on the sound level meter. Tones used varied in frequency from $36 \mathrm{~Hz}$ to $5 \mathrm{kHz}$. The results were consistent with those obtained using the first method : between 2 and $5 \mathrm{kHz}$ attenuation of between 15 and $20 \mathrm{~dB}$ appeared. Below $2 \mathrm{kHz}$ it was variable, but increased in 
some readings to $31 \mathrm{~dB}$. Below $1 \mathrm{kHz}$ the mean then fell again as the frequency decreased, although readings remained variable.

These readings differ most from those reported earlier in respect to higher frequencies. Grimwade, Walker and Wood (1970) and Bench (1968) have found increasing attenuation at frequencies above $1 \mathrm{kHz}$. In the sheep this lack of gross amounts of attenuation at higher frequencies could be of particular significance as its auditory system is most sensitive at higher frequencies. According to Wollach (1963) auditory acuity is best at frequencies around $9 \mathrm{kHz}$; Ames and Arehart (1972) report a lower figure (about $7 \mathrm{kHz}$ ) but this is much higher than the most sensitive frequency in human hearing. It should be born in mind, however, that we do not know at what developmental stage the sheep achieves normal adult hearing.

Sounds from inside the sheep were recorded with the hydrophone system connected directly to the frequency analyser. When the ewe was engaged in some specific type of activity if was possible to trigger the Spectrum Analyser to get an instantaneous record, or, if the sound was fairly homogeneous, it was found preferable to average over several seconds. An averaged record taken from a time when the ewe was drinking is given in figure 1. Measurements of the sound levels occurring with different

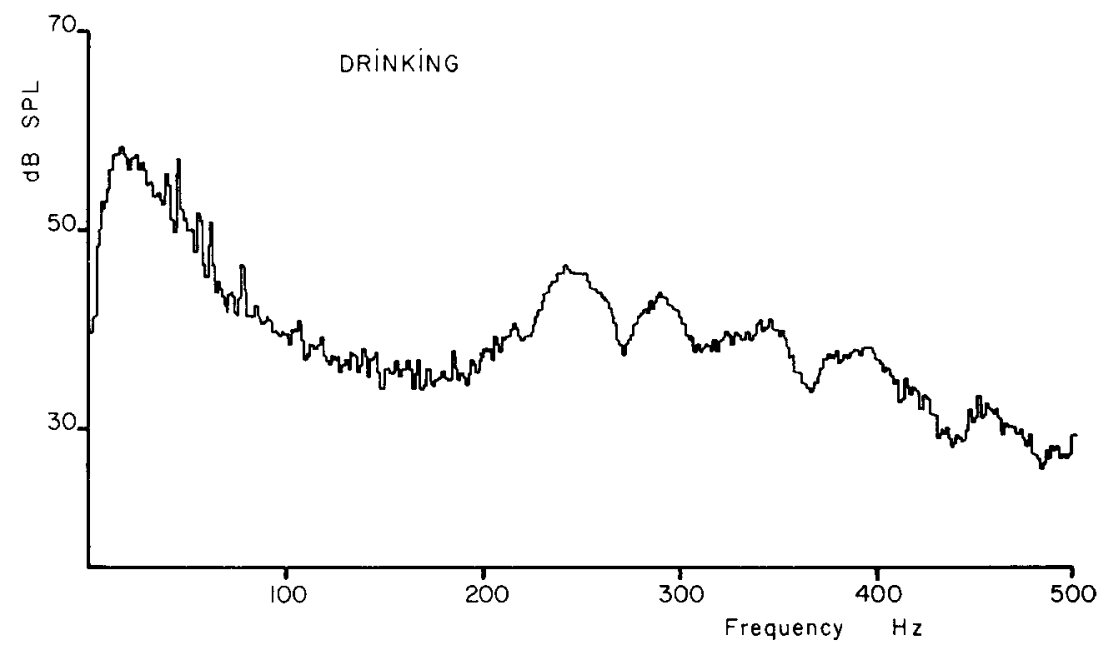

FIG. 1. - Intrauterine sound level recorded in a pregnant ewe when drinking.

types of activity were obtained by measuring peaks*. In this way we found that signals occurring when the animal was quiet ranged from peaks of $60 \mathrm{~dB} S \mathrm{SL}$ at frequencies below $25 \mathrm{~Hz}$ to be lost in the noise ** inherent in the hydrophone system at $200 \mathrm{~Hz}$; when the ewe was chewing the cud (one of the few rhythmic sounds heard)

* Data given actually represent the RMS at the peaks.

** The hydrophone system had a noise level approaching $30 \mathrm{~dB}$ SPL, rising to $60 \mathrm{~dB}$ SPL at very low frequencies. This is an aspect of the work which we hope to improve in the future. Peaks of $30 \mathrm{~dB}$ SPL are however normally designated as « faint » in work on sound. 
peaks varied from about $63 \mathrm{~dB}$ SPL at just below $25 \mathrm{~Hz}$ to $35 \mathrm{~dB}$ SPL just above $400 \mathrm{~Hz}$; eating and drinking sounds varied from a maximum of $58 \mathrm{~dB}$ SPL just below $25 \mathrm{~Hz}$ to become indistinguishable from amplifier noise at $450 \mathrm{~Hz}$. Very little sound energy occurred above the noise level at frequencies higher than $1 \mathrm{kHz}$ and no peaks above $50 \mathrm{~dB}$ SPL occurred above $500 \mathrm{~Hz}$ at times when we were recording. When the sheep was moving actively the sound level peaked at $75 \mathrm{~dB}$ SPL just above $25 \mathrm{~Hz}$. The loudest sound recorded (designated in the notes as the ewe « blowing ») peaked at $14 \mathrm{~Hz}$ and $87 \mathrm{~dB}$ SPL.

The fact that this internal noise tends to be of rather low frequency agrees with the work of Grimwade, Walker and Wood (1970) but the level at which the sounds occurred was very low indeed in comparison with earlier reports. But what distinguishes our results most markedly from earlier findings is that the uterine environment contained quite long periods of relative quiet, when no sound energy above about $50-60 \mathrm{~Hz}$ could be distinguished from the noise inherent in our recording system.

To return to the question of heart sounds or pulsations from the maternal cardiovascular system, we did not hear these in the sheep. We checked our recording system by holding a hydrophone firmly against the outside of the sheep's flank and under these conditions it was possible to hear heart beats, the sound peaking at $50-60 \mathrm{~Hz}$. Peaks around these frequencies and below did occur in most of our recordings of internal sound, but at those low frequencies the human threshold for sound is fairly high (the minimum audible level at $50 \mathrm{~Hz}$ is above $40 \mathrm{~dB}$ and it rises steeply below $50 \mathrm{~Hz}$ according to Robinson and Dadson, 1956). It seems possible, and indeed rather likely, that sounds from the cardiovascular system are there, in the amniotic fluid, but given some attenuation through the uterine wall, they are below at least the human threshold for sound.

It seems to us now that the acoustic situation within the amniotic fluid of the sheep is very different from that outside the uterine wall or at the cervix in human subjects. There seems to be a much greater possibility of the fœius hearing sounds from outside the mother than was formerly believed. This suggests a wide field for investigation bearing on foetal and neonatal life. In the coming winter we are planning to improve our techniques and to continue with this investigation.

Colloque «La relation parentale» Nouzilly, France, juin 1979.

Acknowledgments. - We are deeply indebted to Dr. Brian Moore of the Cambridge Psychological Laboratory, for information and advice on the subject of hearing and the more technical aspects of sound.

Résumé. L'environnement sonore de l'utérus a été étudié chez deux brebis gravides par l'implantation d'un hydrophone sur le cou du fœtus dans les dernières semaines de la gestation. La stimulation par son d'amplitude connue ef l'usage de microphones calibrés et d'un «Narrow Band Spectrum Analyser » type 2031 de Bruel et Kjaer, ont permis d'évaluer :

1. L'intensité d'atténuation des diverses fréquences sonores après passage au travers des tissus maternels et du fluide amniotique.

2. Le niveau absolu de son produit par la mère et qui pénètre l'amnios. 
3. La reconnaissance du son extérieur (par exemple, la voix humaine) quand il est enregistré à l'intérieur de l'utérus.

Un problème encore en suspens est notre impuissance à entendre le son produit par le système cardiovasculaire de la mère - son que l'on admet généralement comme étant un stimulus dominant pour le fœetus.

\section{References}

AMES D. R., AREHART L. A., 1972. Physiological response of lambs to auditory stimuli. J. Anim. Sci., 34, 994-998.

BENCH J., 1968. Sound transmission to the human foetus through the maternal abdominal wall. $J$. Genet. Psychol., 113, 85-87.

BENCH J., ANDERSON J. H., HOARE M., 1970. Measurement system for fetal audiometry. J. Acoust. Soc. America, 47, 1602-1606.

BENCH R. J., MENTZ D. L., 1975. On the measurement of human foetal auditory response. Symp. Zool. Soc. Lond., 37, 23-40.

GOTTLIEB G., 1971. Development of species identification in birds : An enquiry into the prenatal determinants of perception. Univ. Chicago Press.

GRIMWADE J. C., WALKER D. W., WOOD C., 1970. Sensory stimulation of the human foetus. Austr. J. ment. Ret., 2, 63-64.

IMPEKOVEN M., 1971. Prenatal experience of parental calls and pecking in the laughing gull (Larus atricilla L.). Anim. Behav., 19, 475-480.

MUROOKA H., KOIE Y., 1976. Analyse des sons utra-utérins ef leurs effets tranquillisants sur le nouveau-né. J. Gynécol. Obstét. Biol. Reprod., Paris, 5, 367-376.

ROBINSON D. W., DADSON R. S., 1976. A redetermination of the equal-loudness relations for pure tones. Br. J. appl. Physiol., 7, 166-181.

SALK L., 1960. Effects of normal heart beat sound on the behaviour of the new-born infant : implications for mental health. World ment. Health, 12, 168-175.

TSCHANZ B., 1968. Trottellummen (Uria aalse). Die Enstehung der personlichen Beziehung zwischen Jungrogel und Eltern. Z. Tierpsychol., 4, 1-103.

VINCE M. A., 1979. Postnatal effects of prenatal sound stimulation in the guinea pig. Anim. Behav, 27, 908-918.

WOLLACH C. H., 1963. The auditory acuity of the sheep. J. Audit. Res., 3, 121-132. 